УДК 546.287

\title{
ОСОБЕННОСТИ МЕХАНИЧЕСКОЙ ОБРАБОТКИ РИСОВОЙ ШЕЛУХИ ДЛЯ ПРОВЕДЕНИЯ ТВЕРДОФАЗНОГО ВЗАИМОДЕЙСТВИЯ ДИОКСИДА КРЕМНИЯ С ПОЛИФЕНОЛАМИ
}

\author{
(C) Е.Г. Шаполова", О.И. Ломовский
}

\author{
Институт химии твердого тела и механохимии СО РАН, ул. Кутателадзе, \\ 18, Новосибирск, 630128 (Россия), e-mail: shapolova@solid.nsc.ru
}

\begin{abstract}
Особенностями рисовой шелухи являются высокие прочностные характеристики, химическая стабильность, высокая зольность, низкая питательная ценность, обусловленные составом и строением данного типа сырья. Целью работы стало определение оптимальных методов механической обработки для проведения твердофазного взаимодействия диоксида кремния рисовой шелухи с полифенольными соединениями. Проведено сравнение разных режимов обработки растительного сырья. Показано, что при использовании диоксида кремния из растительного сырья для твердофазного взаимодействия с полифенолами необходимо как разрушение супрамолекулярного комплекса диоксида кремния с лигноцеллюлозной матрицей, достигаемое при тонком измельчении, так и пластическая деформация фазы диоксида кремния с образованием реакционных центров. Использование измельчающих аппаратов с истирающим и сдвиговым типом действия, в том числе роликовых мельниц, позволяет реализовать данные процессы. Следует отметить, что предпочтительно использовать диоксид кремния в составе растительного сырья, так как для проведения реакции между диоксидом кремния и полифенолами с получением поверхностных комплексов необходимо наличие силанольных групп. При получении диоксида кремния из рисовой шелухи стандартными методами большая часть гидроксильных групп отжигается, что существенно уменьшает реакционную способность.

Ключевые слова: рисовая шелуха, диоксид кремния, механохимия, поверхностное взаимодействие, комплексы кремния с полифенолами.
\end{abstract}

\section{Введение}

Установлено, что соединения биогенного кремния являются наиболее физиологически активными по сравнению с неорганическими силикатами [1]. Наибольшей биологической активностью достигают комплексы кремния с органическими соединениями [2]. В работах [3, 4] на модельных системах (силикагель и пирокатехин, силикагель и дигидрокверцетин, силикагель и катехины зеленого чая) показано, что осуществить взаимодействие диоксида кремния с полифенольными соединениями можно посредством твердофазного механохимического метода. При совместной механической обработке реагентов происходит образование поверхностных комплексов кремния с полифенолами за счет взаимодействия гидроксильных групп полифенолов с силанольными группами диоксида кремния. При добавлении воды комплексы переходят в раствор, существенно увеличивая концентрацию водорастворимых мономерных форм кремния.

Наиболее перспективным возобновляемым источником биогенного диоксида кремния является рисовая шелуха, в которой его содержание может достигать до $20 \%$ по массе. В рисовой шелухе кремний находится в составе гидроксилированного аморфного кремнезема, в форме силикагеля. Диоксид кремния является компонентом клеток или клеточной стенки. Главным образом кремнезем концентрируется у внешних поверхностей растительных тканей, где образует целлюлозно-кремнеземную мембрану [5]. В работе [6] сообщается о существовании кремния в растениях в виде протонированного кремнийоргани-

Шаполова Елена Геннадиевна - младший научный сотрудник, кандидат химических наук, e-mail: shapolova@solid.nsc.ru

Ломовский Олег Иванович - заместитель директора, доктор химических наук, профессор

\footnotetext{
* Автор, с которым следует вести переписку.
} ческого комплекса. В спектрах РФЭС образцов рисовой шелухи $\mathrm{Si} 2$-электроны представлены двумя компонентами с энергиями 101,7 и 103,4 эВ, с соотношением $1: 3$ [7]. По мнению авторов, компонента 
с большей энергией связывания относится к $\mathrm{SiO}_{2}$, с меньшей энергией - к атомам кремния, входящим в состав органических фрагментов. При обработке рисовой шелухи в шаровой мельнице и при нагревании выше $350{ }^{\circ} \mathrm{C}$ образцов пик в спектрах, соответствующий минимальной энергии, значительно уменьшается, в результате чего на поверхности образцов увеличивается содержание кремнезема.

На поверхности диоксида кремния рисовой шелухи присутствует адсорбированная вода. Температурная зависимость интенсивности сигнала ${ }^{1} \mathrm{H}$ протонов воды образцов шелухи риса показывает наличие двух типов воды: подвижной воды и воды, протоны которой связаны с атомами кислорода силанольных групп [8]. Как показано в ряде исследований, фаза воды необходима для проведения механохимических превращений [9].

Целью данной работы является определение оптимальных режимов механической обработки для проведения твердофазного взаимодействия диоксида кремния рисовой шелухи с полифенольными соединениями.

\section{Материалы и методы}

Реактивы и материаль. В работе использовали шелуху риса Oryza sativa, сорт Лиман, Краснодарский край, порошок зеленого чая Camelia sinensis (L.), ООО «Дагомысчай», Краснодарский край (ТУ 9191 003-00570186-04), $\left(\mathrm{NH}_{4}\right)_{2} \mathrm{MoO}_{4}$ (х.ч., ГОСТ 3765-78), $\mathrm{H}_{2} \mathrm{SO}_{4}$ (х.ч., ГОСТ 4204), $\mathrm{Na}_{2} \mathrm{SiO}_{3}$ (ГОСТ 50418-92), $\operatorname{KBr}$ (ч.д.а., ГОСТ 4160-74), пирокатехин (99\%, Alfa Aesar), ацетат аммония (ч., ГОСТ 3117-78), аскорбиновую кислоту (ч.д.а., ГОСТ 4815), щавелевую кислоту (х.ч., ГОСТ 22180-76).

Механическая обработка растительного сырья. Механическую активацию проводили в планетарно-центробежной мельнице АГО-2 (ИХТТМ СО РАН, Новосибирск) с водяным охлаждением барабанов. Подведенная мощность находилась в интервале 1,25-10 Вт/г. Загрузка шаров диаметром 5 мм в стандартный стальной барабан АГО-2 составляла 200 г. Соотношение масс шаров и навески реагентов - 50 : 1 . Использовали роликовую мельницу РМ-20 (ИХТТМ СО РАН, Новосибирск) - проточный активатор с водяным охлаждением. Температурные эксперименты выполняли на на аттриторе, устройство которого аналогично аппаратам, производимым фирмой «Courtesy of Union Process», США). Условия обработки в вышеперечисленном оборудовании представлены в таблице.

Фотометрический анализ выполняли на спектрофотометре «UNICO-2800» (США) с диапазоном 2001100 нм, длина оптического пути - 1 см. Растворение образцов осуществляли в 0,05 М буфере, приготовленном на основе ацетата аммония, при постоянном перемешивании на магнитной мешалке со скоростью 600 об./мин, при гидромодуле 1000 и температуре $25^{\circ} \mathrm{C}$ в течение 4 ч. Супернатант использовали для спектрофотометрического анализа, выполненного по следующей методике. В пробирку емкостью 5 мл отбирали 350 мкл исследуемого раствора. Затем добавляли кислый раствор молибдата аммония (0,5 М) 150 мкл и выдерживали 10 мин. После этого к раствору прибавляли 300 мкл восстановителя - смеси аскорбиновой $(0,4$ М) и щавелевой кислот $(0,7 \mathrm{M})$ и 3,25 мл воды. Через 30 мин проводили фотометрическое измерение при длине волны 810 нм, длина оптического пути составляла 10 мм. При каждом фотометрическом определении одновременно с исследованием растворов проводили калибровку на стандартном растворе, по которой и рассчитывали содержание кремния. Полученные данные использовали для построения кривых растворения.

Электронномикроскопическое исследование проводили на микроскопе Hitachi Table Top (Япония). Дифрактограммы записывали с помощью дифрактометра Bruker (Германия) (излучение СuK- $\alpha$ ). Удельную поверхность образцов определяли по тепловой десорбции аргона на приборе «Сорбиметр М» (Россия). ИКспектры регистрировали на спектрофотометре «Инфралюм-801» (Россия) в диапазоне 400-4000 см ${ }^{-1}$ в таблетках с $\mathrm{KBr}$ (4 мг образца на 540 мг KBr). Гранулометрический анализ осуществляли на приборе «Микросайзер 201 А» (ПКГ «Гранат», Россия). Термический анализ проводили на приборе синхронного термоанализа STA 449C «Jupiter» (Германия) в токе аргона, скорость нагрева $10^{\circ} \mathrm{C} / \mathrm{мин,} \mathrm{температурный} \mathrm{диапазон} \mathrm{-}$ 28-900 ${ }^{\circ} \mathrm{C}$, масса навесок - 100 мкг.

Параметры механической обработки шелухи риса

\begin{tabular}{l|c|c|c}
\hline \multicolumn{1}{c|}{ Оборудование } & Температура, ${ }^{\circ} \mathrm{C}$ & Время, мин & Частота, об./мин \\
\hline Аттритор & $-195,25,98$ & $10,20,30$ & 200 \\
АГО-2 & $15-20$ & $0,8,1,2,5,10$ & 630 \\
РМ-20 & 25 & $0,8-1$ & 1000 \\
\hline
\end{tabular}




\section{Результаты и обсуждение}

Проведено количественное определение целлюлозы в рисовой шелухе по методике [10]. Содержание целлюлозы составило 36,2\%. Количественное содержание диоксида кремния рассчитывалось исходя из значений, полученных при измерении зольности образцов за вычетом нерастворимой части после кипячения золы с гидроксидом натрия. Содержание диоксида кремния в данном растительном сырье - 15,7\%.

Суммарное содержание диоксида кремния и целлюлозы составляет больше половины массы сухого вещества рисовой шелухи. Это позволяет рассматривать вышеперечисленные полимеры как основообразующие компоненты для исследуемого растительного сырья, обладающие различными физическими свойствами и по-разному откликаются на механическое воздействие.

В процессе механической обработки могут реализоваться процессы хрупкого и вязкого разрушения растительной ткани. Вид разрушения зависит от ряда факторов: состава фаз, структурного состояния, условий нагружения и температуры. При хрупком разрушении трещины распространяются быстро, что обусловливает хорошее измельчение. Вязкое разрушение обусловлено малой скоростью распространения трещины. Однако для проведения химической реакции в ходе механической обработки необходимо разрушать частицы реагентов вязким образом, так как именно пластическая деформация обеспечивает образование химически активных центров.

С целью изучения влияния хрупкого и вязкого механизма разрушения на свойства рисовой шелухи проводили механическую обработку растительного сырья в измельчающем аппарате - аттриторе, обеспечивающем эффективный теплоотвод от стенок барабана и возможность изменения температуры стенок реактора в широких пределах. Обработку проводили при термостатировании реактора жидким азотом или водой при -196, 25 и $98^{\circ} \mathrm{C}$.

Данные микроскопического анализа продуктов обработки приведены на рисунке 1. При температуре механической обработки $98^{\circ} \mathrm{C}$ в основном реализуется процесс пластической деформации и диссипации энергии. При таком механизме воздействия именно светлые ткани, содержащие диоксид кремния, остаются практически без изменений, видны лишь небольшие сколы. Покрывая нижележащие ткани, кремнеземная оболочка препятствует дальнейшему разрушению растительного сырья.

При понижении температуры происходит нарушение супрамолекулярной структуры полимеров, гомогенизация рисовой шелухи, и значительное уменьшение размера частиц.

Фракцию рисовой шелухи с размером частиц менее 300 мкм изучали с помощью анализатора размера частиц «Микросайзер 201». По данным гистограммам (рис. 2) можно заключить, что с повышением температуры обработки в распределении становится больше частиц с большими размерами, средний размер частиц увеличивается.

Так как энергонапряженность при обработке сырья в аттриторе практически не зависит от температуры, то увеличение размера частиц при росте температуры свидетельствует о возрастании доли энергии, которая расходуется на пластическую деформацию субстрата.

Для образцов, полученных при температуре -196 и $25^{\circ} \mathrm{C}$, характерно бимодальное распределение частиц продукта по размерам. Бимодальное распределение связано с наличием двух разных типов частиц. Поскольку в первую очередь рвутся наиболее слабые межмолекулярные связи между тканями, образованными разными типами полимеров, то вероятно разделение лигноцеллюлозной и кремнеземной фаз. Возможно протекание частичной делигнификации. Для образца, полученного при $98{ }^{\circ} \mathrm{C}$ (в режиме пластической деформации), существенное разделение на различные типы тканей не происходит.

Измельченные фракции рисовой шелухи с разным размером частиц исследовали методом термического анализа. Эндотермический максимум при $335^{\circ} \mathrm{C}$ на термограмме целлюлозы соответствует образованию левоглюкозана [11]. Для выделенной фракции частиц с размерами 250-100 мкм пик на $335^{\circ} \mathrm{C}$, характерный для целлюлозы, выражен наиболее ярко. При уменьшении размера частиц его интенсивность значительно снижается. Фракция с размером частиц меньше 50 мкм имеет максимальный пик, соответствующий десорбции воды (около $100{ }^{\circ} \mathrm{C}$ ). Так как в рисовой шелухе вода сорбируется главным образом на поверхности диоксида кремния, то можно предположить, что эта фракция наиболее обогащена диоксидом. Подтверждением предположения стали данные по зольности фракций рисовой шелухи с разным размером частиц. Зольность для образца с минимальным размером частиц составила 20,4\%, для фракции 100-50 мкм - 15,1\%, для фракции 200-100 мкм - 13,6\%. 


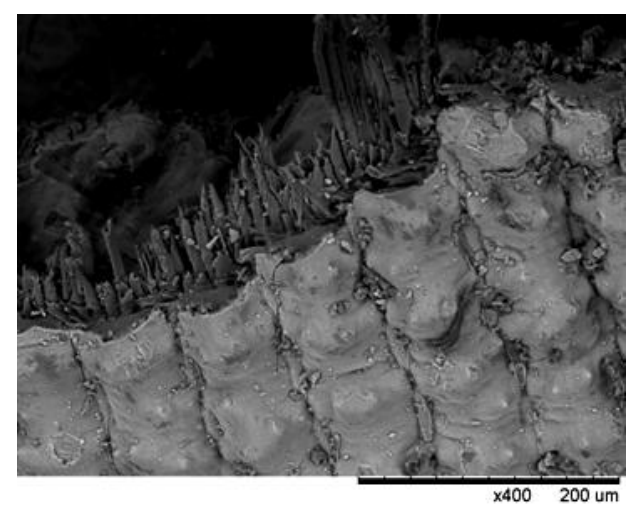

$a$

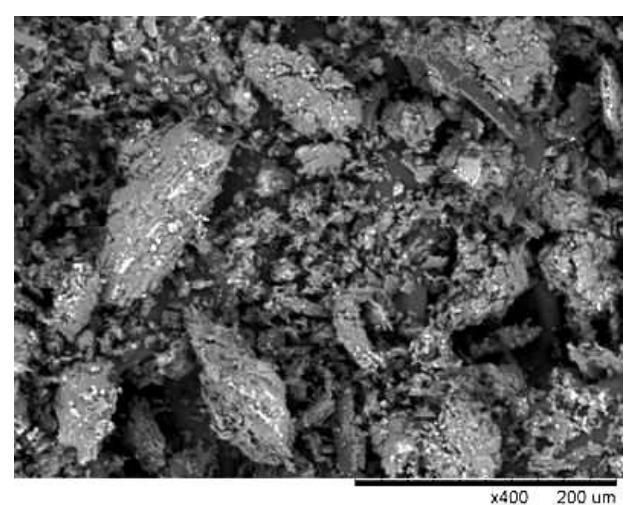

B

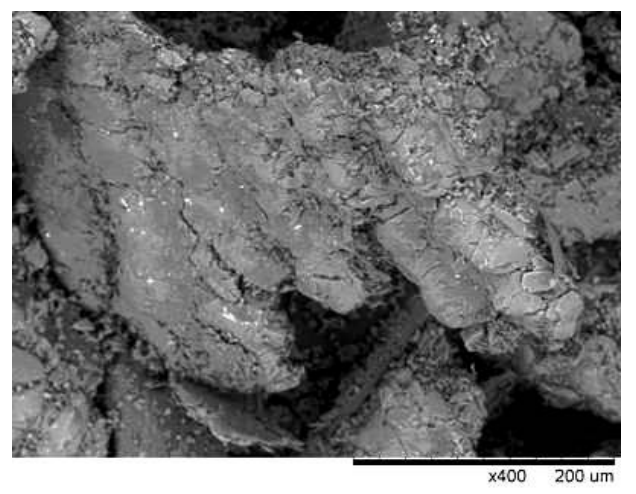

$\sigma$

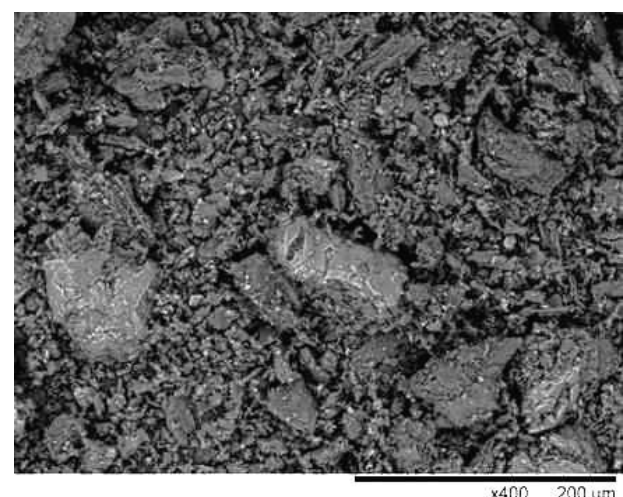

2

Рис. 1. Микрофотографии рисовой шелухи: $a$ - исходной, $\sigma$ - обработанной в мельнице при $98{ }^{\circ} \mathrm{C}, \varepsilon-$ при $25^{\circ} \mathrm{C}$, г- при $-196^{\circ} \mathrm{C}$

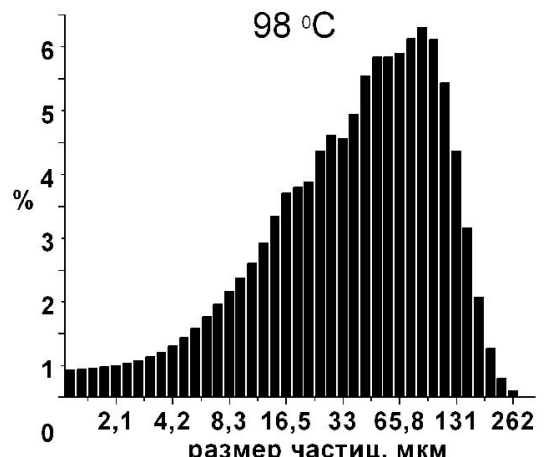
размер частиц, мкм
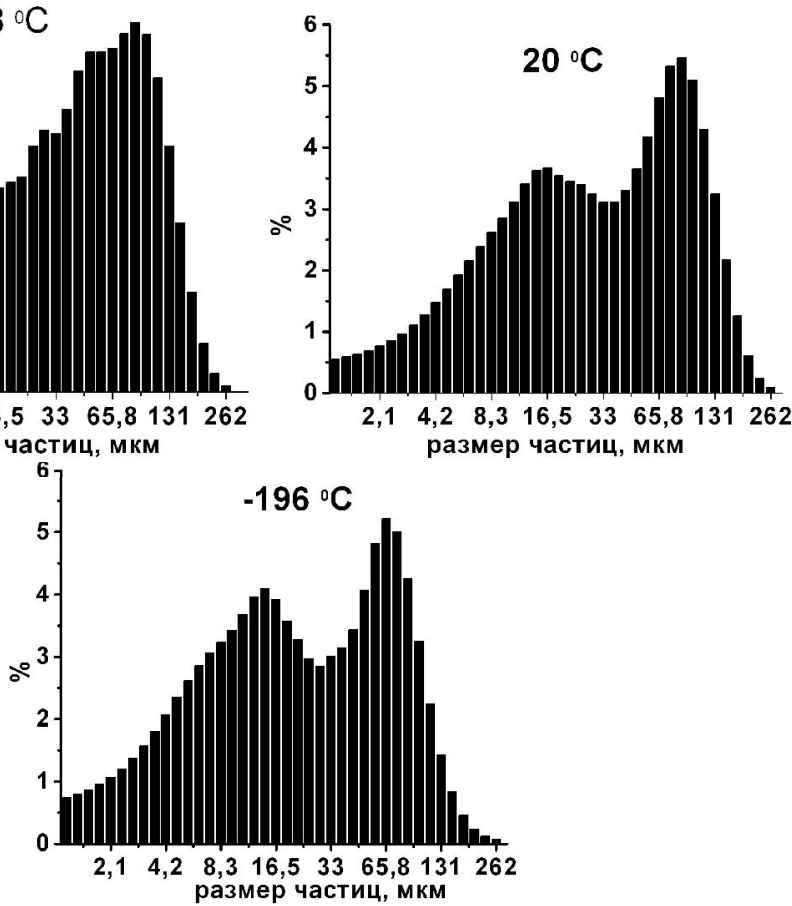

Рис. 2. Количественное распределение частиц по размерам для рисовой шелухи, обработанной в разных температурных режимах 
Доказательством разделения разных типов ткани по фракциям является цвет порошков. Фракция с минимальным размером частиц имеет молочный цвет. С увеличением размера частиц фракции приобретают желтый цвет; так, фракция с размером частиц 200-100 мкм уже имеет ярко-желтый цвет.

Таким образом, частичное разделение на разные типы тканей при механической обработке рисовой шелухи подтверждают химический и термический анализы, значительные различия в цвете фракций с разным размером частиц. Фракция с минимальным размером частиц обогащена диоксидом кремния, крупноразмерная - лигноцеллюлозной.

Для изучения влияния механизма разрушения на разупорядочение целлюлозной матрицы рисовой шелухи был установлен индекс кристалличности по рентгенограммам образцов согласно [12]. Понижение температурного режима приводит к уменьшению индекса кристалличности в 2 раза. В данных режимах, как было показано выше, происходит разрушение кремнеземной оболочки. Лигноцеллюлозная матрица становится открытой для механического воздействия, в результате которого осуществляется разупорядочение и аморфизация биополимеров. В случае преобладания вязкого разрушения (температурный режим $98{ }^{\circ} \mathrm{C}$ ) лигноцеллюлозная матрица надежно экранирована от разного типа воздействий, в том числе и от пластической деформации, вследствие чего целлюлоза практически не аморфизуется. Стоит отметить, что обнаруженный эффект является особенностью рисовой шелухи из-за наличия соединений кремния, так как для большинства растительных материалов и чистых полимеров при вязком разрушении наблюдается аморфизация целлюлозы и уменьшение индекса кристалличности, а при реализации режима хрупкого измельчения индекс кристалличности изменяется незначительно.

Наибольший выход мономерных форм кремния при взаимодействии диоксида кремния с водой достигается при обработке рисовой шелухи при $25^{\circ} \mathrm{C}$ за счет комбинации двух режимов разрушения. Хрупкое разрушение обеспечивает измельчение сырья, разделение тканей и увеличение удельной поверхности с 0,4 до 2,2 м²/г. При вязком разрушении протекает пластическая деформация, характеризующаяся изменением положения атомов относительно друг друга, изменением углов связей и уменьшением энергии связей. Появляется возможность снизить энергетические затраты проведения реакции на стадии взаимодействия реагента с поверхностью диоксида кремния.

В режиме преимущественно хрупкого измельчения рисовой шелухи достигается наибольшая удельная поверхность продукта $\left(2,1 \mathrm{~m}^{2} / \Gamma\right)$, однако не происходит эффективной активации фазы диоксида кремния. Об этом свидетельствует одинаковая растворимость диоксида кремния в данном образце и в образце, обработанном в режиме пластического течения, удельная поверхность которого в три раза меньше $\left(0,7 \mathrm{~m}^{2} / \Gamma\right)$. Таким образом, увеличение удельной поверхности вносит сопоставимый вклад с пластической деформацией в реакционную способность диоксида кремния при данных условиях.

Проведено сравнение эффективности мельниц-активаторов с различным типом механического воздействия. Показано, что для разупорядочения структуры сырья необходимы сдвиговые и истирающие воздействия, разрушающие межмолекулярные связи между тканями. Данные процессы реализуются при применении роликовых мельниц. Ударное воздействие мельниц со свободным ударом менее эффективно, так как шары, ударяясь о прочную кремнеземную поверхность на более мягкой подложке из лигноцеллюлозы, не могут в значительной степени разрушить диоксид кремния (рис. 3).

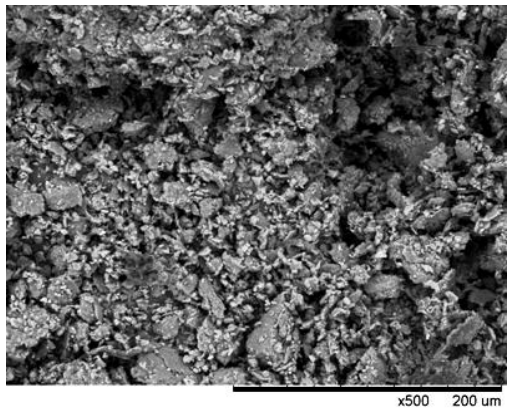

a

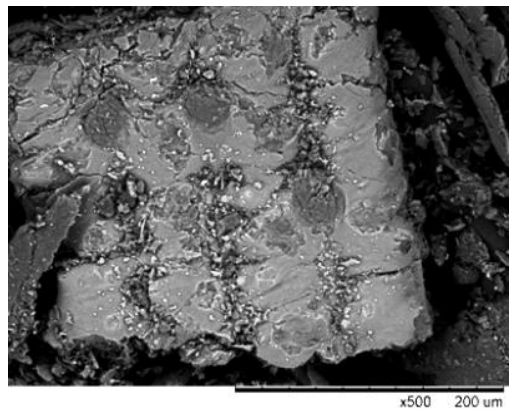

$\sigma$

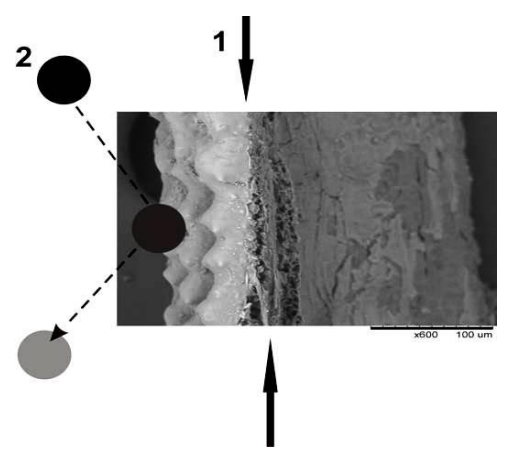

B

Рис. 3. Микрофотографии рисовой шелухи после обработки: $a$ - в роликовой мельнице, $\sigma$ - в планетарной мельнице, в - предположительная схема воздействия роликовой мельницы (1) и планетарной мельницы

(2) на рисовую шелуху. 
При обработке рисовой шелухи в роликовой мельнице происходит значительное нарушение морфологии растительных тканей (рис. 3-а), заключающееся в уменьшении размеров частиц и удалении кремнеземной оболочки, гомогенизации смеси частиц, отвечающих различным тканям исходной биомассы. Происходит увеличение удельной поверхности от 0,4 до $2,3 \mathrm{~m}^{2} / \Gamma$, в то время как удельная поверхность для образца, обработанного в планетарной мельнице, существенно не изменяется $\left(0,6\right.$ м $\left.^{2} / \Gamma\right)$. В результате наблюдаемых процессов облегчается доступ молекул реагента к поверхности, что должно приводить к более высоким скоростям взаимодействия.

\section{Механохимическое взаимодействие диоксида рисовой иелухи с полифенолами}

В случае использования рисовой шелухи в качестве источника диоксида кремния возможно применение непосредственно исходного растительного сырья или же выделение целевого компонента. Основным способом извлечения диоксида кремния является окислительный обжиг рисовой шелухи при температурах $600-1100{ }^{\circ} \mathrm{C}$.

Диоксид кремния получен из рисовой шелухи по методике, обеспечивающей максимальный выход и чистоту продукта и заключающейся в предварительном кислотном гидролизе и последующем прокаливании при $700{ }^{\circ} \mathrm{C}$ до достижения постоянной массы [13].

Полученный диоксид кремния подвергался механохимической обработке на роликовой мельнице с галлокатехинами зеленого чая в весовом соотношении $10: 1$. Ниже приводится сравнение кривых растворения при рН 6,8 продуктов механохимической обработки (рис. 4а).

Таким образом, увеличение растворимости диоксида кремния из механокомпозита на основе прокаленной рисовой шелухи незначительно. Аналогичный результат получен и на модельных системах при растворении механокомпозита на основе прокаленного силикагеля [14]. Очевидно, что при прокаливании осуществляется отжиг гидроксильных групп на поверхности диоксида кремния, определяющих реакционную способность при механохимическом взаимодействии с полифенолами. Кроме того, происходит потеря подвижной фазы воды, которая обеспечивает транспорт реагентов, увеличивает диэлектрическую проницаемость среды. Поэтому предпочтительно использовать гидроксилированный диоксид кремния непосредственно в матрице шелухи риса.

Это позволяет избежать дополнительной стадии выделения, сократить соответствующие энергетические затраты на обжиг и сохранить активные центры для взаимодействия. Растворимость диоксида кремния из механокомпозита на основе исходной рисовой шелухи (рис. 4-б) в несколько раз выше, чем из активированной рисовой шелухи без добавок, что свидетельствует о выходе в раствор водорастворимых комплексов кремния с полифенолами.

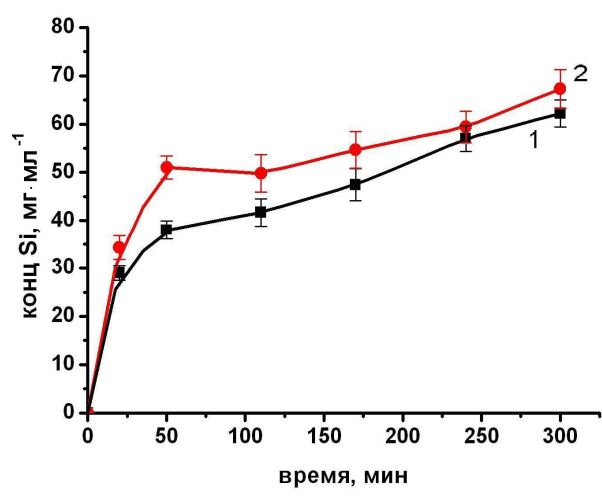

$a$

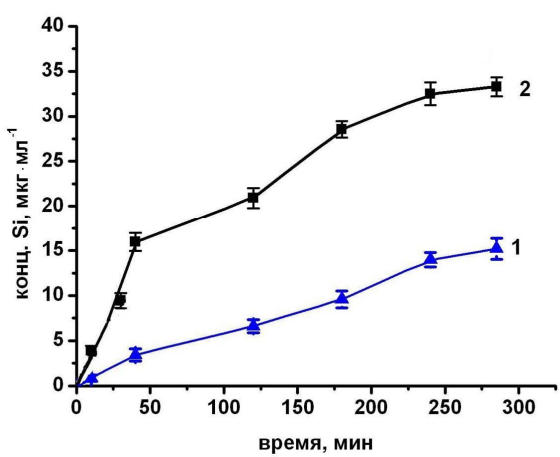

6

Рис. 4. Кривые растворения диоксида кремния: $a$ - полученного прокаливанием рисовой шелухи, $\sigma-$ из растительной матрицы: 1 - активированный, 2 - совместно активированный с катехинами зеленого чая 
В ИК-спектре композита на основе исходной рисовой шелухи значительно уменьшается интенсивность валентных колебаний гидроксильных групп диоксида кремния. Наблюдаются сдвиг в коротковолновую область и исчезновение сигналов изолированных силанольных групп на 3738 см-1. Происходит расщепление пика с двойного (1053, $\left.1080 \mathrm{~cm}^{-1}\right)$ до четверного, с появлением новых сигналов при 1036 и 1102 см$^{-1}$, которые могут соответствовать образованию Si-O-C связи, при взаимодействии полифенолов с силанольными группами. Полученные результаты аналогичны изменениям в ИК спектрах модельной системы силикагель - пирокатехин и свидетельствуют об образовании поверхностных комплексов [14].

\section{Bыводы}

1. Эффект механической активации компонентов рисовой шелухи для проведения взаимодействия диоксида кремния с полифенолами проявляется максимально при реализации смешанного режима разрушения (хрупкого и вязкого). При этом происходит увеличение удельной поверхности от 0,5 до 2,2 м²/г, уменьшение размеров частиц, разупорядочение структуры с аморфизацией целлюлозной фазы, разделение на разные типы тканей и активация поверхности диоксида кремния с образованием активных центров (напряженных и разорванных связей).

2. Для проведения твердофазной реакции между диоксидом кремния рисовой шелухи и полифенолами предпочтительно использование аппаратов с истирающим и сдвиговым типом действия, например, роликовых мельниц. Изученные процессы механической активации растительного сырья применены для проведения механохимического взаимодействия с полифенолами.

3. Для проведения реакции между диоксидом кремния и полифенолами необходимо наличие силанольных групп, поэтому предпочтительно использовать диоксид кремния в составе растительного сырья. При получении диоксида кремния из рисовой шелухи стандартными методами большая часть гидроксильных групп отжигается, что существенно уменьшает реакционную способность.

\section{Список литературы}

1. Van Dyck. K., Van Cauwenbergh R., Robberecht H., Deelstra H. Bioavailability of silicon from food and food supplements // Fresenius J Anal Chem. 1999. N363. Pp. 541-544.

2. Воронков М.Г., Зелчан Г.И., Лукевиц, Э.Я. Кремний и жизнь. Рига, 1978. 587 с.

3. Shapolova E.G., Lomovsky O.I. Mechanochemical solubilization of silicon dioxide with polyphenol compounds of plant origin // Russian Journal of Bioorganic Chemistry. 2013. Vol. 39. N7. Pp. 765-770.

4. Shapolova E.G., Lomovsky O.I. Silicon dioxide-flavonoid composites synthesizes by mechanochemical method // Journal of International Scientific Publications: Materials, Methods \& Technologies. 2013. Vol. 7. N3. Pp. 39-48.

5. Park B., Wi S.G., Lee K.H., Singhb A.P., Yoon T., Kimb Y.S. Characterization of anatomical features and silica distribution in rice husk using microscopic and micro-analytical techniques // Biomass and Bioenergy. 2003. Vol. 25. Pp. 319-327.

6. Кабата-Пендиас А. Микроэлементы в почвах и растениях. М., 1989. 440 с.

7. Земнухова Л.А., Николенко Ю.М. Исследование рисовой шелухи и продуктов ее переработки методом рентгеновской фотоэлектронной спектроскопии // Журнал общей химии. 2011. Т. 81. №4. С. 602-608.

8. Земнухова Л.А., Бабушкина Т.А., Климова Т.П. Исследование методом ЯМР ${ }^{1} \mathrm{H}$ состояния воды в образцах аморфного кремнезема из рисовой шелухи // Журнал общей химии. 2007. Т. 77. №6. С. 917-922.

9. Avvakumov E., Senna M., Kosova N., Soft Mechanochemical Synthesis: a Basis for New Chemical Technologies. Boston, 2001. $200 \mathrm{p}$.

10. Ермакова А.И. Методы биохимического исследования растений. Л., 1987. 430 с.

11. Домбург Г.Э. Термический анализ целлюлозы. Методы исследования целлюлозы. Рига, 1981. С. 111-125.

12. Segal L., Creely J.J., Martin A.E., Conrad C.M. An empirical method for estimating the degree of crystallinity of native cellulose using the X-Ray difractometer // Text. Res. J. 1959. Vol. 29. N10. Pp. 786-794.

13. Земнухова Л.А., Федорищева Г.А., Егоров А.Г., Сергиенко В.И. Исследование условий получения, состава примесей и свойств аморфного диоксида кремния из отходов производства риса // Журнал прикладной химии. 2005. Т. 78. №2. С. 324-328.

14. Шаполова Е.Г., Королев К.Г., Ломовский О.И. Механохимическое взаимодействие диоксида кремния с хелатирующими полифенольными соединениями и получение растворимых молекулярных форм кремния // Химия в интересах устойчивого развития. 2010. Т. 18. №5. С. 663-668.

Поступило в редакиию 23 декабря 20142. 
Shapolova E.G. ${ }^{*}$, Lomovskij O.I. SPECIFICS OF MECHANICAL TREATMENT OF RICE HUSK FOR CARRYING OUT SOLID-PHASE INTERACTION OF SILICA WITH POLYPHENOLS

Institute of Solid State Chemistry and Mechanochemistry SB RAS, ul. Kutateladze, 18, Novosibirsk 630128 (Russia), e-mail: shapolova@solid.nsc.ru

Rice husk is characterized by high-strength characteristics and chemical stability, has a low-nutritional value, a low bulk density, and a high ash content.The goal of the present work is the development of a treatment method method for obtaining compositions based on polyphenols from the plant raw material and biogenic silicon dioxide from rice husk. Efficiencies of mills with different types of grinding were compared. The most effective grinders for the high-quality treatment of rice husk are roller and attrition mills. The mechanical treatment causes an increase in the specific surface, a decrease in particle size, structural disordering with the amorphization, separation into different kinds of tissues and formation of active sites on silica. In the case when rice husk is used as the source of silicon dioxide for interaction with polyphenols, it is preferred to use the initial plant raw material, silanol group-containing. The interaction of silanol group of rice husk silica with polyphenols result in the formation of surface complexes.

Keywords: rice husk, silicon dioxide, mechanical treatment, roller mill, processing conditions, surface interaction, silicon complexes with polyphenols.

\section{References}

1. Van Dyck. K., Van Cauwenbergh R., Robberecht H., Deelstra H. Fresenius J Anal Chem. 1999, no. 363, pp. 541-544.

2. Voronkov M.G., Zelchan G.I., Lukevic, Je.Ja. Kremnij i zhizn'. [Silicon and life]. Riga, 1978, 587 p. (in Russ.).

3. Shapolova E.G., Lomovsky O.I. Russian Journal of Bioorganic Chemistry, 2013, vol. 39, no. 7, pp. 765-770.

4. Shapolova E.G., Lomovsky O.I. Journal of International Scientific Publications: Materials, Methods \& Technologies, 2013, vol. 7, no. 3, pp. 39-48.

5. Park B., Wi S.G., Lee K.H., Singhb A.P., Yoon T., Kimb Y.S. Biomass and Bioenergy, 2003, vol. 25, pp. 319-327.

6. Kabata-Pendias A. Mikrojelementy v pochvah i rastenijah. [Trace elements in soils and plants]. Moscow, 1989, 440 p. (in Russ.).

7. Zemnuhova L.A., Nikolenko Ju.M. Zhurnal obshhej himii, 2011, vol. 81, no. 4, pp. 602-608. (in Russ.).

8. Zemnuhova L.A., Babushkina T.A., Klimova T.P. Zhurnal obshhej himii, 2007, vol. 77, no. 6, pp. 917-922. (in Russ.).

9. Avvakumov E., Senna M., Kosova N. Soft Mechanochemical Synthesis: a Basis for New Chemical Technologies. Boston, 2001, $200 \mathrm{p}$.

10. Ermakova A.I. Metody biohimicheskogo issledovanija rastenij. [Methods of biochemical research plant]. Leningrad, 1987, 430 p. (in Russ.).

11. Domburg G.Je. Termicheskij analiz celljulozy. Metody issledovanija celljulozy. [Thermal analysis of pulp. Research Methods cellulose]. Riga, 1981, pp. 111-125. (in Russ.).

12. Segal L., Creely J.J., Martin A.E., Conrad C.M. Text. Res. J. 1959, vol. 29, no. 10, pp. 786-794.

13. Zemnuhova L.A., Fedorishheva G.A., Egorov A.G., Sergienko V.I. Zhurnal prikladnoj himii, 2005, vol. 78, no. 2, pp. 324-328. (in Russ.).

14. Shapolova E.G., Korolev K.G., Lomovskij O.I. Himija v interesah ustojchivogo razvitija, 2010, vol. 18, no. 5, pp. 663-668. (in Russ.).

Received December 23, 2014

Revised March 16, 2015

\footnotetext{
* Corresponding author.
} 